\title{
Gamification of Decentralized Ledger for Credit Card Application using Blockchain
}

\author{
Rohmat Taufiq \\ Doctor of Computer Science, Bina Nusantara Graduate \\ Program, \\ Bina Nusantara University, \\ Jakarta, Indonesia 11480 \\ rohmat.taufiq@binus.ac.id \\ Wayan Suparta \\ Doctor of Computer Science, Bina Nusantara Graduate \\ Program, \\ Bina Nusantara University, \\ Jakarta, Indonesia 11480 \\ drwaynesparta@gmail.com
}

\author{
Agung Trisetyarso \\ Doctor of Computer Science, Bina Nusantara Graduate \\ Program, \\ Bina Nusantara University, \\ Jakarta, Indonesia 11480 \\ atrisetyarso@binus.edu
}

\begin{abstract}
We propose a credit card application using blockchain to improve the approval, transparency and security process. Some studies explain the use of blockchain technology in credit card applications but have not described the concept and architecture. Therefore, this study describes and describes the architecture of using credit cards for credit card applications. The motivation of this researchis to explain the implementation of blockchain technology, especially the decentralization process of ledgers in credit card applications. Next, we propose architecture and algorithms for credit card applications using blockchain. Theconclusion in this study is a decentralized ledger for credit card applications that allows peer-to-peer transactions, decentralized credit card applications that are not bound by geographical boundaries, have two advantages for debtors and the banking industry. In addition, the architecture ismade using a credit card for application credit cards and an explanation of how the architecture works.
\end{abstract}

Keyword: Gamification, decentralized ledger, credit card application, blockchain.

\section{INTRODUCTION}

The term Gamified and gamification are new emerging research fields. At present, the meaning of "gamification" can be referred to as a broad definition range: for example, attaching game components to the software. One of the authors explained that gamification is an approach that supports the improvement of skills and ensures that this method can be centralized and can be utilized for the benefit of all humans in order to accelerate the global challenges that can be faced [2]. Many researchers define gamification with the same meaning that gamification is the intentional use of game elements to complete not game activities [3] [4] [5] [6] [13].

Recently, organizations and business processes have experienced a revolution because of the blockchain presence: using blockchain organizations and businesses can also be decentralized because of jurisdiction over boundaries rather than centralized jurisdictions that hold full control of the center. This provides several benefits for businesses such as increasing transparency, reducing costs, and more validity [7]. A joint ledger or better known as a distributed ledger is shared and synchronized data that is geographically spread across many sites. so that data integrity, availability, and durability are also high, so it needs to be replicated and synchronized in all locations [8]. Centralized system administrators and one control point in a decentralized ledger do not exist. this is what distinguishes a centralized system [9].

A credit card is a card or mechanism that allows cardholders in their activities, especially in the transaction process such as: buying goods, traveling and eatingsomewhere without having to overshadow cash [10]. Blockchain is a transaction distribution database in general ledger that uses cryptography and transaction processing in accordance with consensus mechanisms [11]. From previousresearch, there is a gap that research on blockchain technology has been carried out in developed countries such as (England, United States, Australia, Scotland, Germany, Japan, France, Italy, China, etc.). However, research onblockchain applications for credit card applications is still rare. Especially in developing countries research onblockchain for credit card archiving is a bad implementation.

Blockchain in the credit card business has been studied by Blenkinsop 2018, describing the use of cryptocurrency on blockchain for credit and debit card applications, the use of credit and debit cards in the payment process provides several benefits: "more credible, efficient, cost-effective, measurable and flexible" [28 ] In addition, Moghe also stated that credit cards are quite large businesses, such as Visa, which handles around 150 million transactions every day. The main principle of blockchain is "decentralization" which will reduce costs for intermediaries or third parties, because with third parties, if we borrow \$ 100 with a credit card, we will receive $\$ 96.5$. Therefore, using blockchain technology will use decentralized methods, without third 
parties, all transactions are stored in ledgers, international payments can also be made easier because there are many bank fees to use the blockchain payment system in addition to blockchain security in cryptocurrency credit cards [29 ]

In 2018, Wolfson also explained that the major credit card issuers in Argentina "Naranja" partnered with a blockchain-based network to validate payment cards and travel bidding systems. The achievement of major credit card issuers to implement blockchain technology to advance card embezzlement concerns at ATMs and access all pointof-sale providers, of which around $\$ 2$ billion is embezzled per year throughout. Leaders for friendship with Naranja and $\mathrm{RCN}$, a global peer-to-peer credit network based on the assignment of smart contracts on the Ethereum blockchain to manage users with "loans given tokens" [30].

Credit cards are a big business in Indonesia. According to Bank Indonesia (BI), the value of credit card transactions as of March 2018 reached Rp 755.28 billion. This value increased $9.82 \%$ compared to February 2018 which reached Rp. 687.69 billion [31]. If we pull back starting from 2009-2017 the number of credit cards and the number of transactions has increased. 2009 the number of credit cards was 12.3 million, 2010 reached 13.6 million, $2011=14.8$ million until 2017 fluctuated upwards with a total of 17.2 million. While the number of transactions in 2009 reached 136.7 trillion from year to year experiencing an increase, precisely in 2017 the number of transactions became 297.8 trillion [32]. From the large number of transactions and credit cards in circulation, the problem arises about the process of filling in the credit card submission forms that this time and again led to the swelling of data base banking capacity and less effective and efficient. One solution that could be given was to develop blockchain technology with decentralized ledger model for credit card application.

From the above research, it explains the use of blockchain technology in credit card applications but has not yet described the concept and architecture. Therefore, this study explains and describes the architecture using credit cards for credit card applications.

In our architecture, each block represents a bank and cryptographic has printed on smart contracts where the public key and the key of the cryptographic process depend on the proposed gamification: an application is processed by the bank and will be sent to the blockchain network; if the credit limit on the applicant bank is required, the private key will be released. However, if not, the key will not be released. As shown in Figure V, our blockchain network contains 4 blocks where each block represents the bank.

The motivation of this research is to explain the implementation of blockchain technology, especially the decentralization process of ledgers in credit card applications. Next, we propose architecture and algorithms for credit card applications using blockchain. This is important because similar research on blockchain technology in research credit card processes is still rare, especially in developing countries. Furthermore, this research tries to explain "How can the gamification model be used to approve credit card applications using a Decentralized Ledger with Blockchain Technology?". This study aims to improve credit card applications, so that the approval process is faster, more transparent and safer.

\section{The ReView of Previous Literature}

\section{a. Gamification}

The basic question that arises from gamification is why it must be gamification, because gamification is widely used by people for many activities that have a positive impact. because it can be called a gamification virus and can also make people addicted. for users who are easily addicted must be treated in different ways [4]. Gamification is used to motivate users to benefit through enjoyment, basically motivating behavior. Therefore, gamification can be seen as a hedonic tool for productivity [12].

From an information perspective, gamification work is equipped with lots of information about learning. with gamification users will enjoy doing tasks like playing. See the gamification framework below [14]

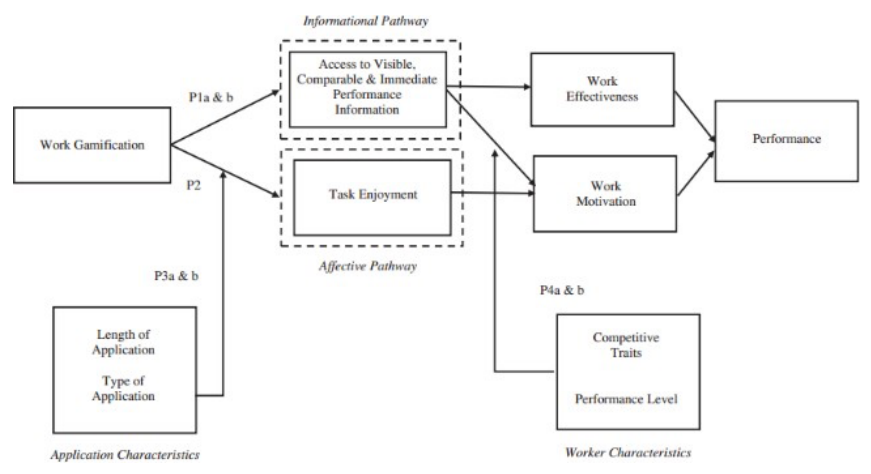

Fig. 1. A Theory of Work Gamification

Gamification can be seen in two dimensions of play / gaming and parts / overall, there are serious games and games. Playful design and toys can be distinguished through the game / play dimensions (Figure 2) [15].

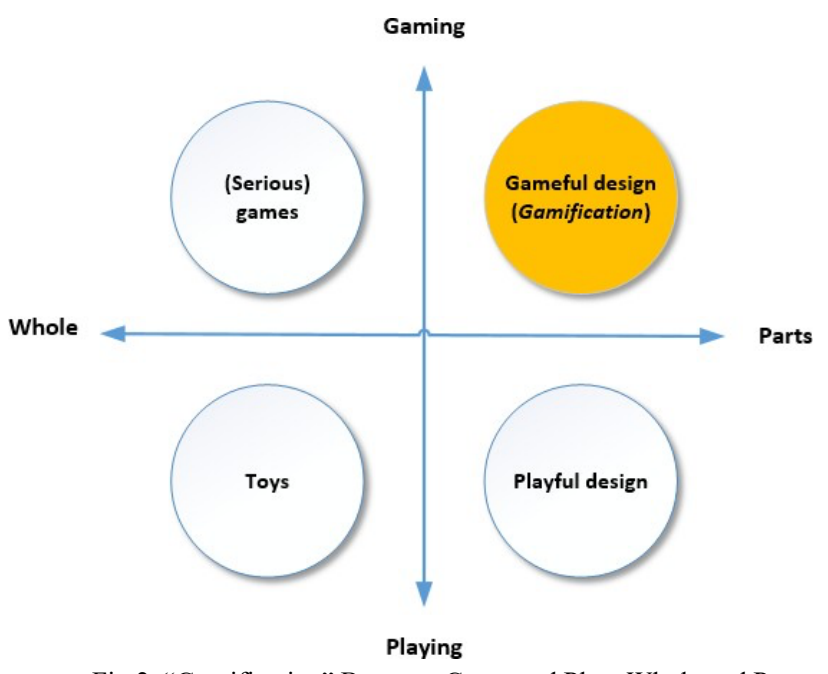

Fig.2. "Gamification" Between Game and Play, Whole and Parts

According to Brinkkemper, there are 3 important points in engineering methods: 1) comprehensive development methods, by including all the resources needed for the 
development of new methods; 2) assemble "method fragments" from basic methods to new situation methods; 3 ) Evaluating the project can provide insight for further development of the situational method. through literature review or research phenomena can be obtained by interviews as the initial and basic knowledge of the method (Figure 3) [16].

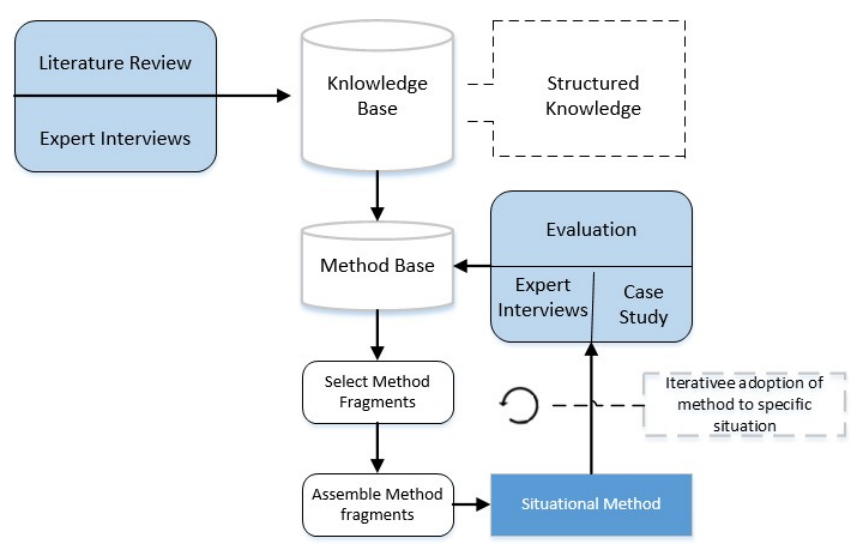

Fig. 3. Situational Method Engineering Approach Followed for Artefacts Development

\section{b. Decentralized ledger}

Decentralized ledgers or distributed ledgers are terms that are in blockchain technology. Bitcoin design, as a "Peer to Peer Electronic Cash System," which can be used by each member to make joint transfers without integrating the central bank [17]. Blockchain technology and Edge computing work together when decentralized from large data that can store and transfer data. Many benefits come from blockchain technology but cannot be overcome but can be used to send and provide chains that can interact [18]. The Distributed Ledger (DLs) is a special implementation of a broader category of 'shared ledger', which is a shared record of data in many parties. blockchain on the ledger is distributed on the data structure. [19].

\section{c. Credit card application}

Credit card brands (Visa, MasterCard, American Express and Diners Club) and marketing activities do indeed represent a global and multicultural and highly competitive business orientation [20]. Credit cards are a fast and efficient method of payment, provided by banks and other financial institutions. In addition, other researchers define that credit cards are cards that are used to take cash or are used for payment processing [21]. The increasing number of credit card owners is a reason for banks and retailers to create strategic networks and create co-branded programs. (Achrol and Kotler, 1999) [22]

We found that cash payments are more familiar than using a credit card. it is done by the type of expenditure, price familiarity and buying and selling habits [23]. Although credit cards have many benefits, the problem for cardholders is how to direct finance [24]

\section{d. Blockchain}

Blockchain technology is a distributed ledger database with all historical transactions stored and distributed in a general ledger with contents containing blocks [25]. Impact of Blockchain Technology on Business Models in the Payment Industry has been research with results illustrated in ten statements synthesized into four areas of thought: Details about the opinions of discussion participants are provided in table I [26].

Table I. Implications of Blockchain Technology for BMs in the Payments Industry

\begin{tabular}{|l|l|l|l|}
\hline $\begin{array}{l}\text { 4 Areas of } \\
\text { Thoughts }\end{array}$ & \multicolumn{3}{|c|}{ 10 Statements } \\
\hline $\begin{array}{l}\text { Blockchain- } \\
\text { enabled services }\end{array}$ & $\begin{array}{l}\text { New Services and } \\
\text { blockchain technology }\end{array}$ & $\begin{array}{l}\text { Obsolete services with } \\
\text { blockchain technology }\end{array}$ \\
\cline { 2 - 4 } & $\begin{array}{l}\text { P2P and direct } \\
\text { transaction }\end{array}$ & $\begin{array}{l}\text { Cross-border } \\
\text { and cross- } \\
\text { currency }\end{array}$ & $\begin{array}{l}\text { Connection } \\
\text { between } \\
\text { contract and } \\
\text { transaction }\end{array}$ \\
\hline $\begin{array}{l}\text { Change Financial } \\
\text { Structure }\end{array}$ & Changed income structure & Cost reduction \\
\hline Potential for BMs & $\begin{array}{l}\text { New business model in } \\
\text { payment }\end{array}$ & $\begin{array}{l}\text { Obsolete business } \\
\text { models in payments }\end{array}$ \\
\hline $\begin{array}{l}\text { New Market } \\
\text { Players }\end{array}$ & Fintech developing blockchain technology \\
\hline
\end{tabular}

[27]

Blockchain technology has 3 challenges in the applied:

- Scalability. With the number of transactions increasing day by day, the blockchain becomes heavy.

- Privacy Leakage. Blockchain is believed to be very safe as users only make transactions with generated addresses rather than real identity

- Selfish mining. Blockchain is susceptible to attacks of colluding selfish miners.

\section{Methodology}

Decentralized Ledger system by blockchain technology can be conceptualized as service innovations in Approved Credit Card Applications. This research at the paper center is based on the Decentralized Ledger of the blockchain technology credit card application. Given the new solution for approving credit card applications with decentralized ledgers on blockchain is new technology.

This research was carried out in 5 steps, there are:

1. Literature review, the amount of literature used is 32 . With the division of disciplines: Gamification 11 literature, Blockchain 11 literature, Credit Card 8 Literature, Finance and Law 1 literature, Credit Cards and Blockchain 1 literature.

2. Study of the credit card application approval process, in this step is done the steps needed for the submission process.

3. Gamification, there are two game models used on this blockchain the first, the banks that do more validation will get more points and second, credit card limits for credit card holders, and others. the payment so that the limit given will automatically decrease even if the credit card is also possible to block.

4. Creating an architectural credit card application on the Blockchain, an architecture created using private keys, public keys, security, mining, list of transactions and general ledger distributed.

5. Create an Algorithm, in the steps it describes the architecture in step 3 in the algorithm using these terms. 
6. Give a conclusion; give a positive conclusion on the use of blockchain for the implementation of credit card submission and approval.

\section{RESUlts AND Discussion}

The credit card application process in Indonesian banking is currently divided into 2 parts, the first for the first and second credit card holders for the second credit card holder or so on.

For ownership of the first credit card with a minimum net income of Rp. 3,000,000 / month. The steps taken are:

1. Fill in the credit card application form completely and correctly

2. Send the application form to the credit card approval at each bank

3. To approve or not, approval of the criteria for using the average bank as follows:

a. ID card copy

b. Age of registration for the main card application Minimum 21-60 years

c. Net income of at least Rp. 3,000,000 / month

d. Photocopy of income

e. Photocopy of NPWP

4. After fulfilling the above, the credit card will be rejected or approved by the Bank

5. The average bank will provide loans of 3-5 x salary for prospective borrowers or around Rp. 9 million - 15 million.

6. Finish

For ownership of a second credit card with a minimum net income of IDR 3,000,000, the requirements must be the same as above starting from filling out the credit card application form again to complete. And if you want to have a third credit card then the prospective debtor must fill in the application form again and follow the terms and conditions apply.

The discussion of the results above is that this research provides a solution for credit card process proposals in general credit card applications with a decentralized ledger with blockchain technology. In figure IV below illustrates the decentralized ledger architecture gamification for credit card applications. Please note the components in the architecture are:

1. Creditors, namely people who will apply for a credit card or credit card owner

2. Application is an application used by creditors to enter the blockchain system or which will be used as a transaction medium. This application can be a web-based system or a smart phonebased system.

3. Security is the security system used in blockchain. Security can be in the form of cryptography, has functions, public keys or private keys.
4. Distributed ledger is a large book that data is stored in a decentralized block. The existing big book can be seen by all members in the blockchain. In the ledger there are names that have block, parent, timestamp, nonce, root and list of transactions.

5. Database is a place to store data. Data stored can be data of members who are in the blockchain, creditor, transaction data, transaction recap that has been done.

6. Banks, banks are described with 4 interconnected data surrounding the ledger. That means the bank can see each creditor transaction simultaneously and the same transaction model.

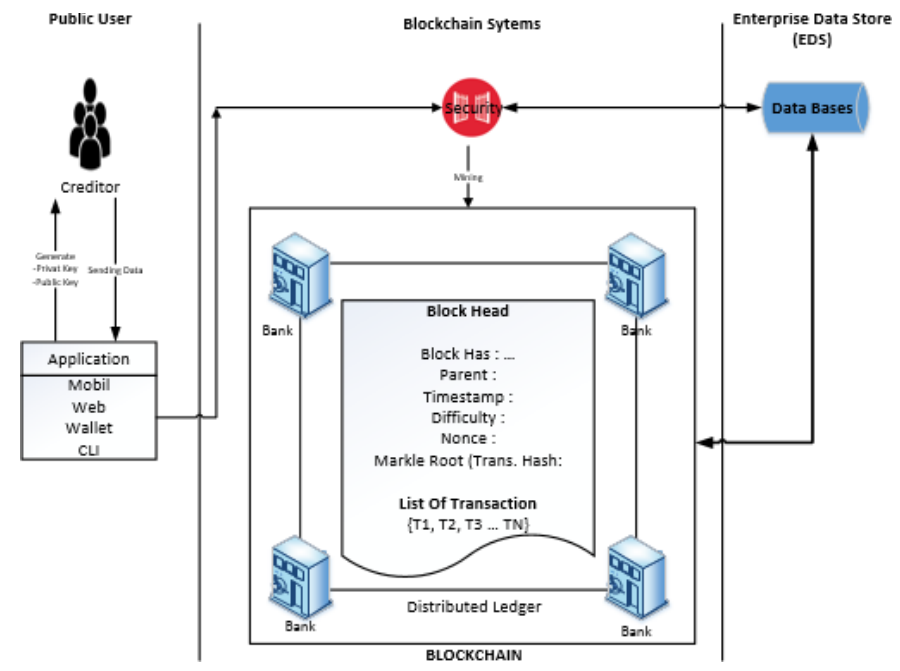

Fig. IV. Credit Card Application using Blockchain

Explanation of how the architecture works is as follows:

1. Prospective creditors send credit card applications via Application (Car, Web, Wallet or CLI)

2. The blockchain system does a cross check whether the prospective creditor has a problem or not from the transaction that has been done.

3. If there is a problem or have been hit by a blacklist then the system does not validate the submission of the person. This means that the blockchain system has crossed automatically.

4. However, if the prospective creditor is free from problems, then the credit card application will be studied and validated by the four banks. (Gamification function) the more banks do validation; the more banks will get points according to the range agreed upon by the 4 banks.

5. After studying each bank will give approval or not to apply for the person's credit card. It can be approved but the limit is reduced from the initial submission.

6 . The creditor can choose which bank matches the creditor's wishes.

7. If the payment is good (gamification function), the limit will automatically be increased according to the creditor's monthly balance, but if the payment is not good, the system will reduce the limit or even close the transaction. 
Journal of Games, Game Art and Gamification Vol. 04, No. 01, 2019 Special Issues: 2018 International Conference of Games, Game Art and Gamification

8. Transactions made by the creditor will be read by the Bank in real time.

9. The data will be stored in the database so that it is easy to search.

From the images and architecture, the researchers describe the algorithm with pseudo code. the credit card pseoudo code model in the blockchain is as follows:

function miningBC

\{application for insert Data Creditor in Blockchain systems with made Hash erlier

Declaration

String dataCreditor;

String dataBC;

String public_key, private_key;

Timestamp timeTransaction;

String previousHash;

String blockHash;

int nonce;

Begin

Read (dataDebitur);

Read (dataBC);

timeTransaksi $=$ read(CurrentSystemTime);

if (dataCreditor $==$ Valid) then

write (public_key); // Sent to Creditor

write(private_key); // Sent to Creditor

if (dataBC $==$ first)

previousHash $=0$;

else previousHash $=$ dataBC; // retrieve Blockchain with

the last index

$/ /$ mining

nonce $=0$;

while (nonce not in (dataBC))

nonce $=$ nonce ++ ;

blockHash $=$ calculateHash(previousHash,

timeTransaksi,nonce); write(blockHash); //Add data in to block end while;

else

write ("info: Submission creditor $=$ reject") end;

function calculateHash(String parentHash, Timestamp

time,nonce)

\{fungsi untuk mengenkripsi dataTransaksi Debitur menjadi satu yang akan disimpan dalam block change\}

Description

String dataHash;

begin

read(parentHash);

read(blockHash);

read(time);

$\operatorname{read}($ nonce);

dataHash $=$ parentHash + time + nonce;

return write(applySHA256(dataHash)); end;

function applySHA256 (String data) :String

\{The function to create data creditor are encrypted using system hashing 256-bit \}

deskripsi

String hexString;

begin

$$
\begin{aligned}
& \text { input(data); } \\
& \text { hexString }=\text { write }(\text { stringtoHash }(\text { data })) \text {; } \\
& \text { return hexString; }
\end{aligned}
$$

end;

\section{CONCLUSION}

Decentralized ledger for credit card application systems enables peer-to-peer transactions, i.e. two individuals can exchange value without relying on a centralized third party. This is a major difference to existing submission credit cards application solutions. Moreover, a decentralized submission credit card application is not bound by any geographical limit: Because of the virtual nature of the submission systems. Generally, the advantage of using decentralized ledger in the blockchain technology had two advantages for debtor and banking industry. Profit for debtors were easy to use, privacy, low transaction fees, real time, need a fast time and efficient. Profit for banking industry with decentralized ledger, the banking industry would know all the transactions made every customer, so it was easier to decide and how much would be given or not.

The special conclusions obtained from this research are made of cards and cryptographic has been printed on the smart contract in which the public and private keys of the cryptographic process are dependent on the proposed gamification: application proceeds by a bank and it will send into the blockchain networks; if the credit limit on a bank of applicants is necessary, the private key will be released.

\section{REFERENCES}

[1]. J. Kasurinen and A. Knutas. "Publication trends in gamification: A systematic mapping study". Computer Science Review. Computer Science Review 27, 33-44, 2018.

[2]. D. Wortley, "Immersive Technology Strategies". Publications Reprints and permissions: sagepub.com/journalsPermissions.nav Simulation \& Gaming 44 (6) $869-881,2013$.

[3]. S. Deterding, R. Khaled, L. E. Necke and D. Dan, "Gamification: Toward a Definition”. Vancouver, BC, Canada. ACM 978-1-45030268-5, 11/05, 2011.

[4]. K. Erenli, The Impact of Gamification. Special focus paper the impact of gamification - recommending education scenarios. IJET Volume 8, Special Issue 1: "ICL2012", January 2013

[5]. G. Zichermann, "Intrinsic and Extrinsic Motivation in Gamification [WWW Document]". Gamification Co. (accessed 07.07.2018), 10/27/2011.

[6]. K. Huotari, J. Hamari, "Defining gamification-a service marketing perspective". In: Proceedings of the 16th International Academic 
Journal of Games, Game Art and Gamification Vol. 04, No. 01, 2019 Special Issues: 2018 International Conference of Games, Game Art and Gamification

MindTrek Conference. Presented at MindTrek'12. ACM, pp. 17-22, 2012.

[7]. I. Bashir, "Mastering Blockchain; Distributed ledgers, decentralization and smart contracts explained". Packt. BirminghamMumbai, 2017.

[8]. A. Lewis, "What's the difference between a distributed ledger an a blockchain?", 20 February 2017.

[9]. R. N. Greeshma R, and S. Sebastian, "BlockChain Technology Centralised Ledger to Distributed Ledger". International Research Journal of Engineering and Technology (IRJET). Volume: 04 Issue: 03 Mar-2017.

[10]. S. R. Bulomine, "Credit Card - A Way To Generate Legitimate Money For Payments". International Journal of Research Granthaalayah Vol.4 (Iss.9: SE): September, 2016.

[11]. R. Beck, M. Avital, M. Rossi, J. B, "Thatcher Blockchain Technology in Business and Information Systems Research". Springer Fachmedien Wiesbaden GmbH, part of Springer Nature, 2017.

[12]. J. Hamari and J. Koivisto, "Why do people use gamification services?". International Journal of Information Management. 34, 419-431, 2015.

[13]. K. Seaborn and D. I. Fels Deborah I. "Gamification in theory and action: A survey. Int. J. Human - Computer Studies”.,2014

[14]. M. Cardador. Teresa, G. B. Northcraft and J. Whicker, "A theory of work gamification: Something old, something new, something borrowed, something cool?". Human Resource Management Review.www.elsevier.com/ locate/humres, 2016.

[15]. S. Deterding, D. Dixon, R. Khaled and L, "From Game Design Elements to Gamefulness: Defining "Gamification"'. Proceedings of the $15^{\text {th }}$ International Academic MindTrek Conference: Envisioning Future Media Environments. Page 9-15, 2011.

[16]. B. Morschheuser, L. Hassan, K. Werder and J. Hamari, "How to design gamifcation? A method for engineering gamifed software". Information and Software Technology, 2017.

[17]. S. Nakamoto, "Bitcoin: A Peer to Peer Electronic Cash System,". available at https://bitcoin.org/bitcoin.pdf, 2018.

[18]. G. Spance, "Blockchain based systems and Edge computing working together as a decentralized public ledger". Fifth International Conference on Software Defined Systems (SDS),
2018.

[19]. World Bank Group, "Distributed Ledger Technology (DLT) and Blockchain". International Bank for Reconstruction and Development / the World Bank1818 H Street NW, 2017.

[20]. B. Charles, P. Audhesh and G. B. Kwabena, "College students' consumption of credit cards. International Journal of Bank Marketing. Vol. 30 Iss 7 pp. 567-585. 30 Januari 2016.

[21]. W. Fu, "Application of the Genetic Algorithm in the Process of the Distibuting Credit Card". ieeexplore.ieee.org/document/6269489, 2012

[22]. W. W. Stephen and K. H. Maxwell. "Airline co-branded credit cards An application of the theory of planned behaviour". 2016- Journal of Air Transport Management, 2016.

[23]. R. Emma, H. Jonas and X. Xiao, "Do consumers pay more using debit cards than cash?". Electronic Commerce Research and Applications, 2015.

[24]. S. S. Alam, R. A. Rahim, Md. R. Haq and Md. A.R Khan, "Journal of Public Administration, Finance and Law". 2014

[25]. L. Juho, R. Matti and K. T. Virpi, "Opportunities and risks of Blockchain Technologies in payments- a research agenda". Proceedings of the 50th Hawaii International Conference on System Sciences, 2017.

[26]. H. Friedrich, P. Francesco and M. Jürgen, "The Impact of Blockchain Technology on Business Models in the Payments Industry". $13^{\text {th }}$ International Conference on Wirtschaftsinformatik, St. Gallen, Switzerland. February 12-15, 2017.

[27]. Z. Zibin, X. Shaon, N. D. Hong and C. Xiangping, "Blockchain Challenges and Opportunities: A Survey". Article in International Journal of Web and Grid Services· December, 2017.

[28]. C. Blenkisop, "Cryptocurrency Startup To Take On 'Outdated' Credit Cards Through Blockchain Payment Protocol”. April 11, 2018.

[29]. S. Moghe, "How Blockchain Can Disrupt The Card Payments Industry And Why it Has't Already"., 2018.

[30]. R. Wolfson, "Major Credit Card Issuer In Argentina Partners With Blockchai-Based Credit Network", 2018.

[31]. Gita Rossiana, Maret 2018 Transaksi Kartu Kredit Naik 9.82\%. CNBC Indonesia. Maret, 2018.

[32]. Steve Marta. General Manager Asosiasi Kartu Kredit Indonesia (AKKI). 2017, jumlah kartu kredit yang beredar berkurang. $02 / 01 / 2018$. 